GEOLOGICA BALCANICA, 47 (2), Sofia, Nov. 2018, pp. 47-58.

\title{
The Botevgrad basin main characteristics and evolution
}

\author{
Zornitsa Dotseva, Dian Vangelov, Ianko Gerdjikov
}

Sofia University “St Kliment Ohridski”, 15 Tsar Osvoboditel Blvd, 1504 Sofia, Bulgaria;

e-mails: zori.geo@gmail.com; dedo@gea.uni-sofia.bg; ian.gerdjikov@gmail.com

(Accepted in revised form: November, 2018)

\begin{abstract}
The Botevgrad basin is one of the numerous Late Pliocene-Quaternary basins developed over the Balkanide orogen. The basin is developed in the West Balkan tectonic zone and on the northern slopes of the Stara Planina Mountain along the Plakalnitsa fault zone, the front of the orogen. The basin was interpreted as half-graben formed on the SW block of the Dragoybalkan fault, considered as the Plakalnitsa fault zone's extensionally reactivated roots. Our data suggest that the basin formation is more complicated and all basin boards are fault predestined. The boards are morphologically well prominent and their geometry is a result of the reactivated older faults' segmentation, combined with the different rheology of the basement lithologies, mainly Palaeozoic low-grade metamorphites and intruded into them syn- to post-metamorphic granitoids. The distribution of the numerous depocentres, the orientation of drainage systems, watershed shape and depositional system migration indicate polyphasic basin evolution. The basin shape and other data, such as criteria for sense of shearing, and intrabasinal push-up blocks' rotation, suggest that the Botevgrad basin should be interpreted as pull-apart basin.
\end{abstract}

Dotseva, Z., Vangelov, D., Gerdjikov, I. 2018. The Botevgrad basin main characteristics and evolution. Geologica Balcanica 47 (2), 47-58.

Keywords: Pliocene-Quaternary basin system, Botevgrad basin, pull-apart basin.

\section{INTRODUCTION}

The processes of extension and core stretching commonly result in rifting and development of sedimentary basins on relatively undeformed zones. On the opposite side are the basins formed over the orogenic belts as effects of post-orogenic relax and extensional/transtensional reactivation of older structures (e.g., Dewey et al., 1993). The Botevgrad basin is an example of polyphasal postorogenic collapse mechanism of basin formation. The last prominent compressional event in the Middle Eocene in the Balkanide orogen was followed by several phases of subsidence, which resulted in the development of sedimentary basin systems with different specific features (Burchfiel and Nakov, 2015; Kounov et al., 2017). The Botevgrad basin is a part of the youngest Late Pliocene-Quaternary basin system.

The first data on the geology of the Botevgrad basin and the surrounding lands were given by Boué (1837), von Hochstetter (1872) and Toula (1882). St. Bončev (1932) published the first geological map of the Botevgrad basin's north-eastern board. Gellert (1932) and E. Bončev (1946) considered the basin formation to be a result of the subsidence of the Dragoybalkan fault's south-western flank, an idea later expanded by Kozhoukharov et al. (1956).

Demirev et al. (1962), E. Bončev (1971), Nenov et al. (1972), Nenov (1976) and Dinkov et al. (1977) described some of the faults outlining the Botevgrad basin, the Late Pliocene-Quaternary age of the deposits and supposed multiple reactivation of the Dragoybalkan fault.

Tzankov et al. (1996) and Roy et al. (1996) suggested a model for the evolution of their "SubBalkan graben system", situated along the Stara Planina Mountain's (Balkan Mountain) southern slopes, by extensional listric tectonics. Burchfiel et al. (2000) considered this basin system, including the Botevgrad basin, as the northern boundary of the "North Aegean Extension Zone".

Angelov et al. (2010a-c) summarised the available information about the Botevgrad basin in the explanatory notes to the geological map of Bulgaria 
in scale M 1:50,000. Some of the tectonic problems of the area were outlined by Gerdjikov et al. (2015).

The Botevgrad basin is accepted as part of the Pliocene-Quaternary basin system but shows some differences, e.g., position, shape, sedimentary fill, and mechanism of formation and evolution. The results of field studies, published data and drainage system analysis allow us to suggest a different model for the basin formation and evolution.

\section{GEOLOGICAL SETTING}

The Botevgrad basin is the only basin of the system situated on the frontal parts of Balkan fold-thrust belt (Vangelov et al., 2013) and in the frames of the West Balkan tectonic zone (Figs 1, 2). It is developed along one of the most prominent tectonic boundaries of Bulgaria - the Plakalnitsa fault zone (Fig. 1). Evidence of compressional/transpressional deformation phases related to Variscan, Early and Late Alpine times, separated by extensional events between some of them, has been found. This multiphase deformational history is well documented both on the NE board of the Botevgrad basin (i.e., the Dragoybalkan ridge) and in the surrounding areas by Variscan low-grade metamorphic overprint, Variscan and Early Alpine brittle-ductile deformation and several stages of Early and Late Alpine brittle shearing. The complex evolution reflects on the heterogeneity of the Plakalnitsa fault zone's frontal parts, where two domains can be distinguished: Lyutidol-Lipnitsa to the northwest and Temush-Urvich to the southeast. These domains differ in both lithological composition and style of deformation.

The Lyutidol-Lipnitsa domain is represented by a narrow leading imbricate thrust fan and backthrusts, forming positive flower structure. The subthrust zone is over than $2 \mathrm{~km}$, including slices of Triassic to Palaeocene sedimentary rocks separated by low-angle thrust planes (Figs 3-5). Orthogonal to the main trend of the zone low-amplitude sinistral and dextral strike-slip shear zones were also docu-

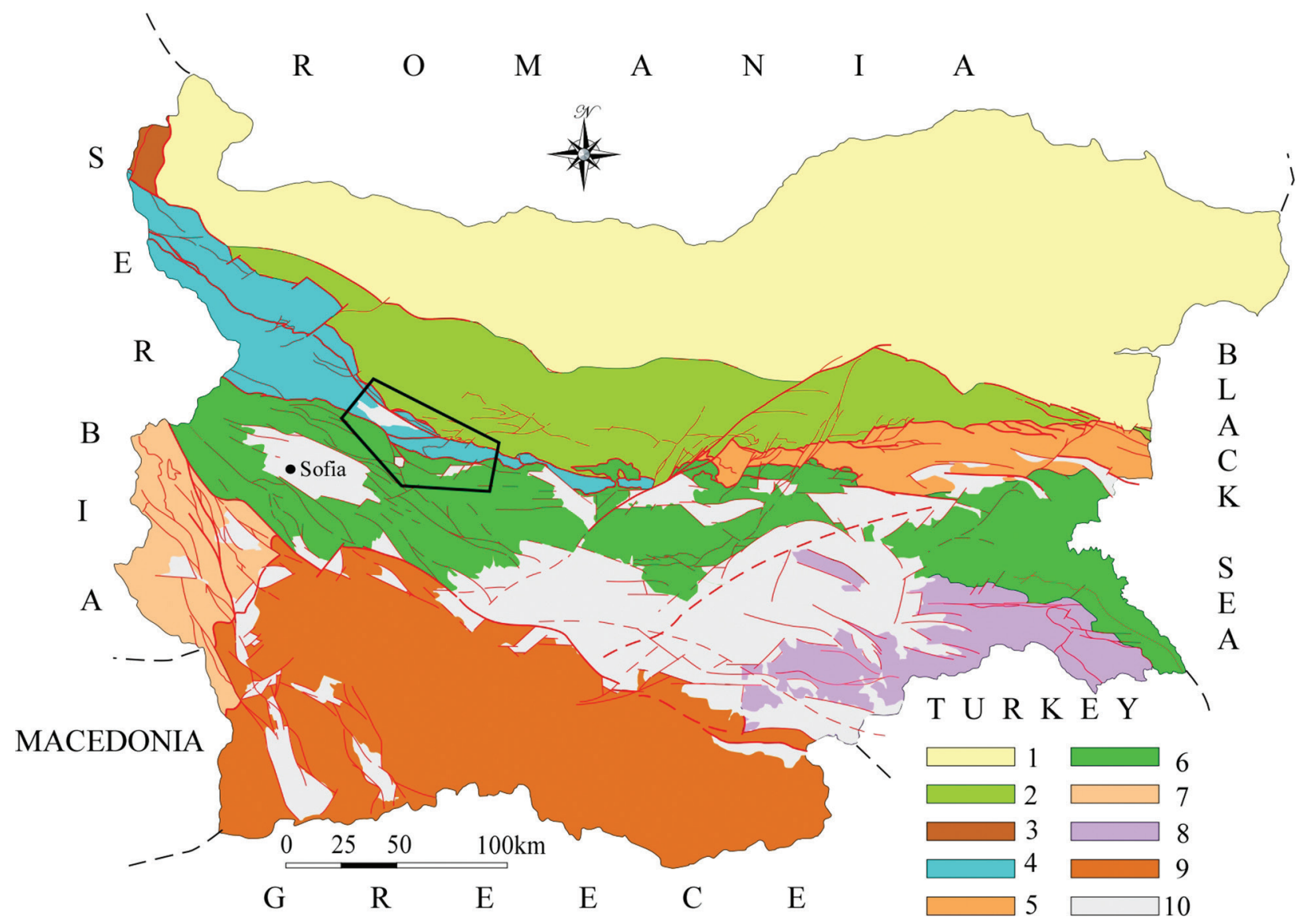

Fig. 1. Schematic tectonic map of Bulgaria (after Ivanov, 1998; Vangelov et al., 2013). 1 - Moesian platform; 2 - Fore-Balkan Zone; 3 - Kula Zone (South Carpathians); 4 - West Balkan Zone; 5 - East Balkan Zone; 6 - Srednogorie Zone; 7 - Kraishte Zone; 8 - Sakar-Strandzha Zone; 9 - Rhodope massif; 10 - overimposed post-compressional basin systems (late Eocene-Quaternary). 


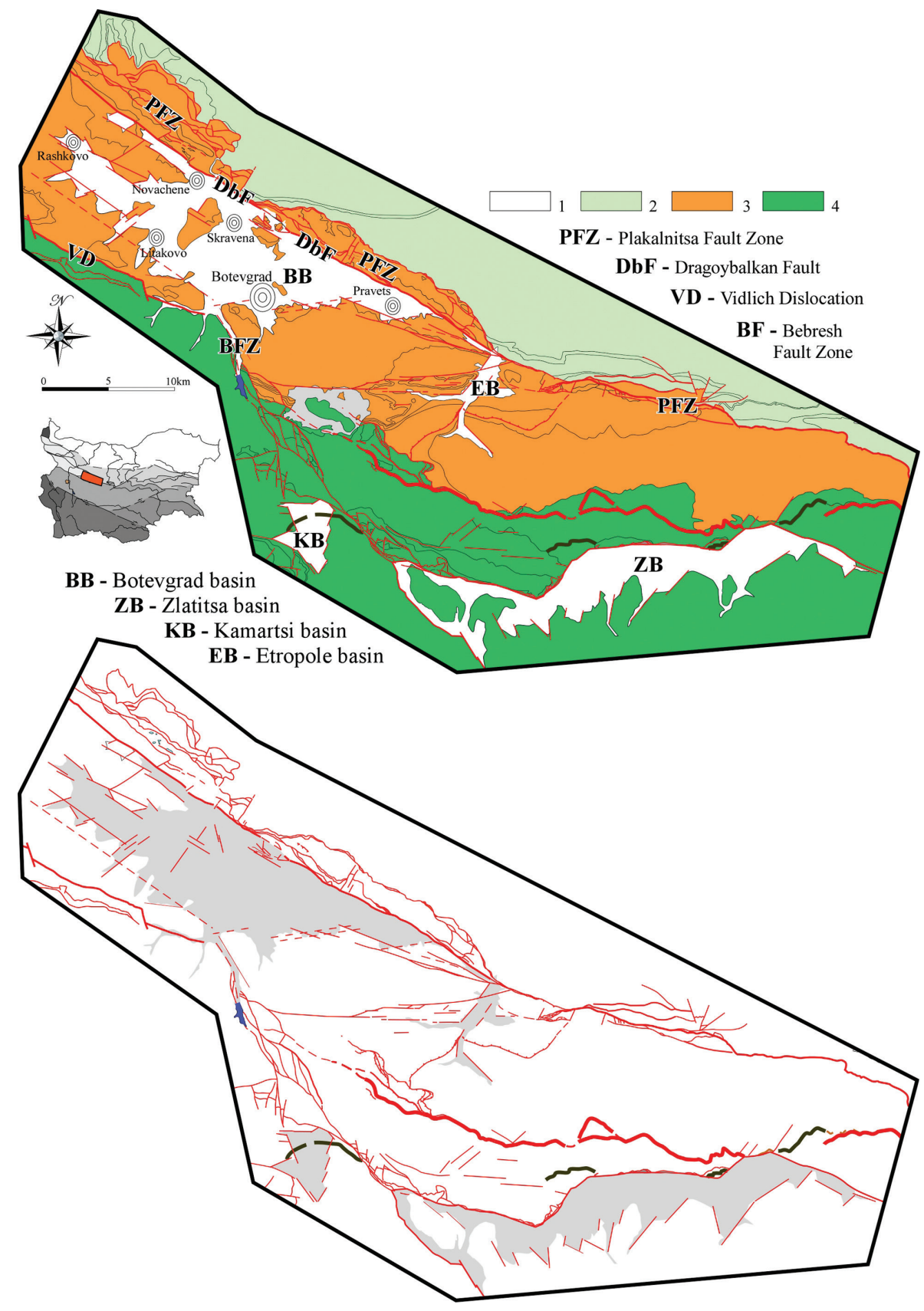

Fig. 2. Simplified tectonic map of the Botevgrad basin and surrounding studied lands. 1 - late Pliocene-Quaternary basins; 2 Fore-Balkan Zone; 3 - West Balkan Zone; 4 - Srednogorie Zone.

mented. This domain is limited from the east by a dextral strike-slip fault, east of Skravena Village (Figs 3, 5).

The SE Temush-Urvich domain is characterised by less-intensive deformation, very narrow subthrust zone, presence of "Ribaritsa"-type metamorphosed granitoids (Angelov et al., 2010), and oblique to the main zone trend synthetic fault planes, indicating compressional and dextral displacement
(Figs 3-6). The brittle-ductile shear zone (most probably Early Alpine in age, based on examples from the surrounding areas, e.g., Kashana shear zone) crops out in the western part of the domain. Between the two domains, the Plakalnitsa zone is only a few tens of metres wide.

The Plakalnitsa fault's strike is about $130^{\circ}$, oblique to the strike of the Triassic-Eocene sediments' bedding plane in the footwall, at least to the 


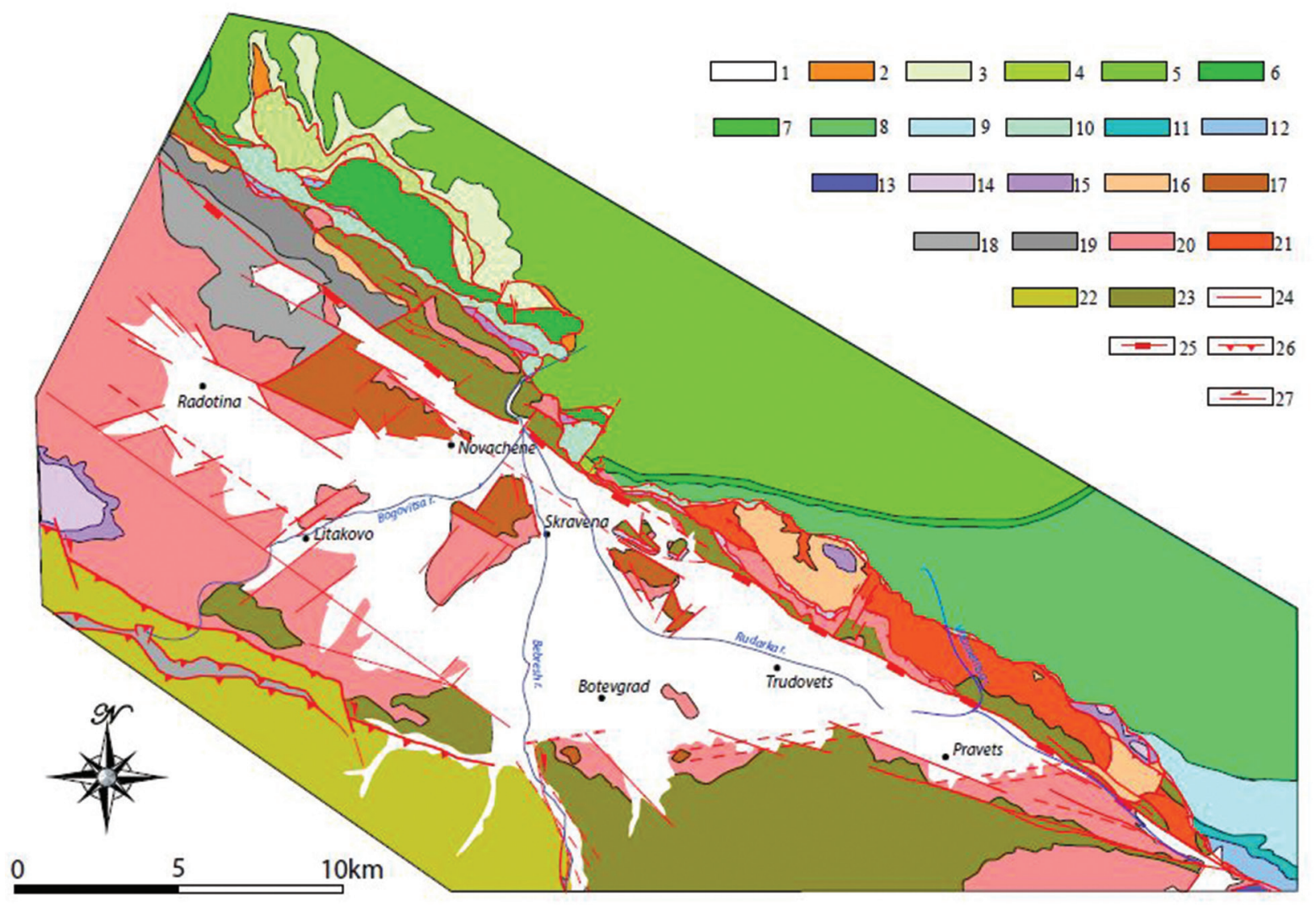

Fig. 3. Geological map of the Botevgrad basin area (modified after Angelov et al., 2008, 2010a, b). 1 - Pliocene-Quaternary; 2 - Palaeogene; 3 - Maastrichtian-Palaeocene; 4 - Sumer Fm. (Aptian-Albian); 5 - Roman Fm. (Aptian-Albian); 6 - Vratsa Urgonian Group; 7 - Paraurgonian sediments; 8 - Kamchiya and Gorna Oryahovitsa fms (Valanginian-Barremian); 9 - Slivnitsa Fm. (Tithonian-Berriasian); 10 - Neshkovtsi and Cherni Osam fms (Tithonian-Berriasian); 11 - Bov and Polaten fms (Bathonian); 12 - Etropole Fm. (Aalenian-Bajocian); 13 - Lower Cretaceous; 14 - Middle-Upper Triassic; 15 - Lower Triassic; 16 - Permian sediments; 17 - Permian magmatites; 18 -Upper Carboniferous magmatites; 19 - Upper Carboniferous sediments; 20 - Variscan granitoids; 21 - Ribaritsa metagranites; 22 - Palaeozoic anchimetamorphic complex; 23 - Palaeozoic green-schist complex; 24 fault; 25 - normal fault; 26 - nappe; 27 - strike slip fault.

valley of the Malak Iskar River. Eastwards, the orientation changes to almost W-E direction, and the kinematics transfers from transpressional to compressional.

In all previous publications concerning the Botevgrad basin (after Gellert, 1932, and E. Bončev, 1946), the Dragoybalkan fault is considered as the main structure controlling the basin evolution. Ivanov et al. (2004) and Petrov (2005) suggested that it is a part of the Plakalnitsa fault zone's roots, which have been extensionally reactivated during the Late Pliocene-Quaternary (Fig. 2).

The other regional fault zones located nearby the Botevgrad basin are the Vidlich dislocation and the Bebresh fault zone, but they bear no evidence of direct influence on its evolution (Figs 2, 3).

In general, the Botevgrad basin is developed over the pre-Alpine basement, which is composed of low-grade metamorphites and intruded into them syn- to post-Variscan granitoids (Figs 3 , 4). In the NW parts of the basin boards, Late Carboniferous and Permian terrestrial, non-metamorphosed coarse-grained deposits and volcanic rocks also crop out. The occasional exotic outcrops of intensively deformed Triassic carbonates into Palaeozoic metamorphites in the intrabasinal push-up blocks confirm the ideas of Ivanov et al. (2004) and Petrov (2005) for a negative flower structure that originated in a transpressional and/or transtenssional setting (Figs 4, 6).

\section{CHARACTERISTICS OF THE BOTEVGRAD BASIN}

The Botevgrad basin is elongated in a WNW-ESE direction, with a length of more than $25 \mathrm{~km}$ and 


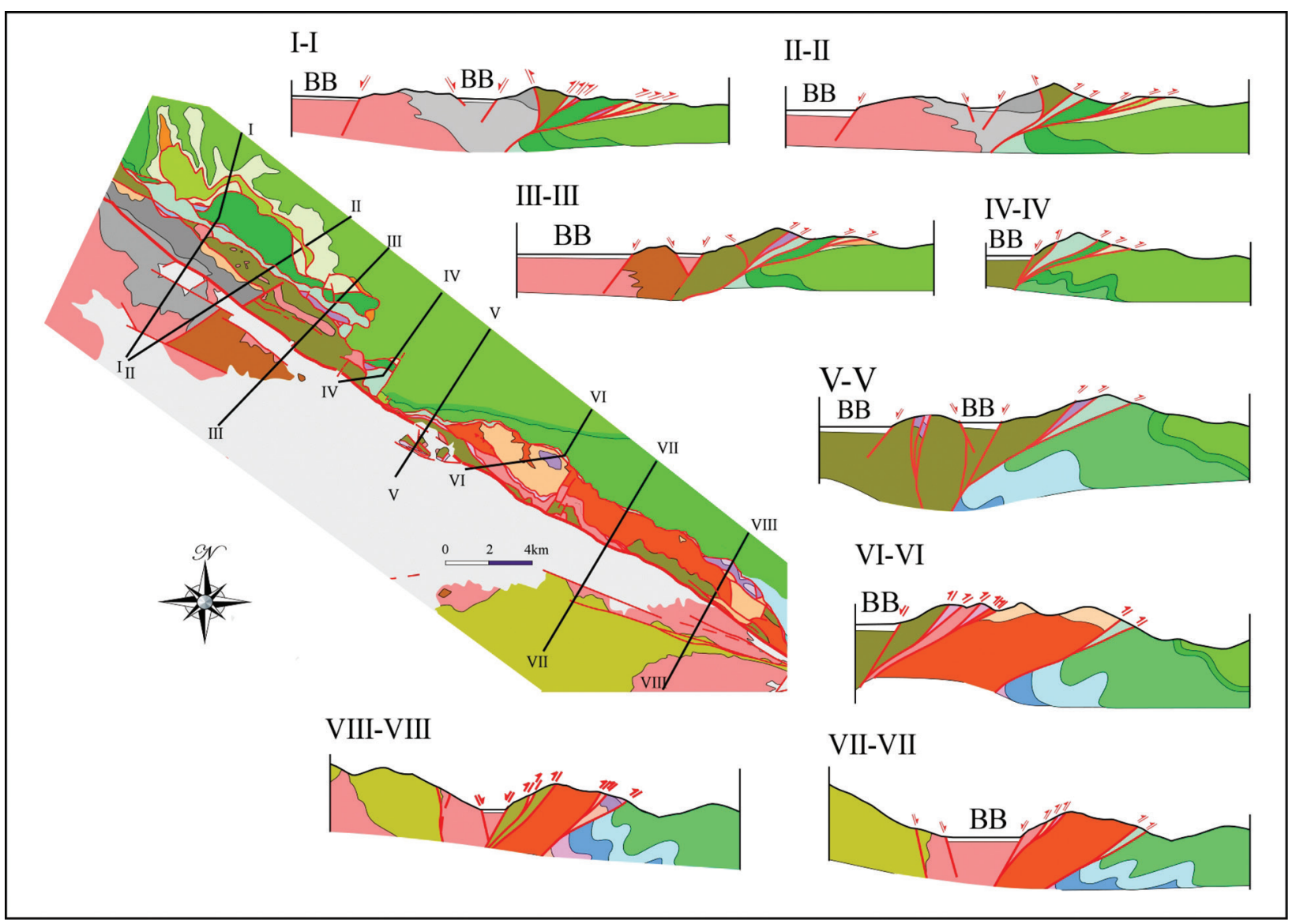

Fig. 4. Schematic cross-section across the NE board of the Botevgrad basin (BB).

maximum width of $8 \mathrm{~km}$. It is characterised by specific shape, drainage system, sedimentary-fill thickness and depocentre distribution. The basin's NE board is linear, controlled by the Dragoybalkan fault, and morphologically well expressed (Fig. 5). The other faults outlining the basin are local, with different orientations (Fig. 6). They are organised in a segmented pattern with secondary faults and relay ramps after the first expansion of the accommodation space and its outlining in a basinwards-propagating system. The geometry of the fault planes is obscured by the incised drainage systems and the alluvial and proluvial fans and aprons, but some preserved segments suggest primary linear geometry.

Most probably, due to the short length and segmentation of the other faults outlining the basin, previous authors (e.g., Kozhoukharov et al., 1956; E. Bončev, 1971; Nenov, 1976; Tzankov et al., 1996) characterised the Botevgrad basin as a halfgraben along the Dragoybalkan fault. The numerous secondary faults in the frames of the basin and their orientation indicate combination of extension and dextral translation; nevertheless, most of the crite- ria for sense of shearing have likely resulted from previous more intensive tectonic phases, later reactivated transtenssionally. This is well visible in Fig. 6 , where all recognised faults align in the centre and result in a logical rose-diagram.

Polyphasal evolution of initial dextral transtension followed by extension, reported by Vangelov et al. (2010) for the Karlovo basin, could also be suggested for the Botevgrad basin. Nenov (1976) supposed at least three subsidence events controlling the depositional systems. This can be proved by analysis of the prograding single or coalescent alluvial fans or slope aprons and also by the distribution and timing of the depocentres during the basin evolution (Figs 7, 8). Along the southern board, and especially in the northwestern part of the basin, the fans show step-like architecture with wider, low-angle distal parts versus shorter and steeper younger proximal parts towards the mountain front (Fig. 7b), which indicates retrogradation towards the mountain front. At the same time, during the fieldwork, incision of the present-day drainage system and formation of new alluvial fans propagating 


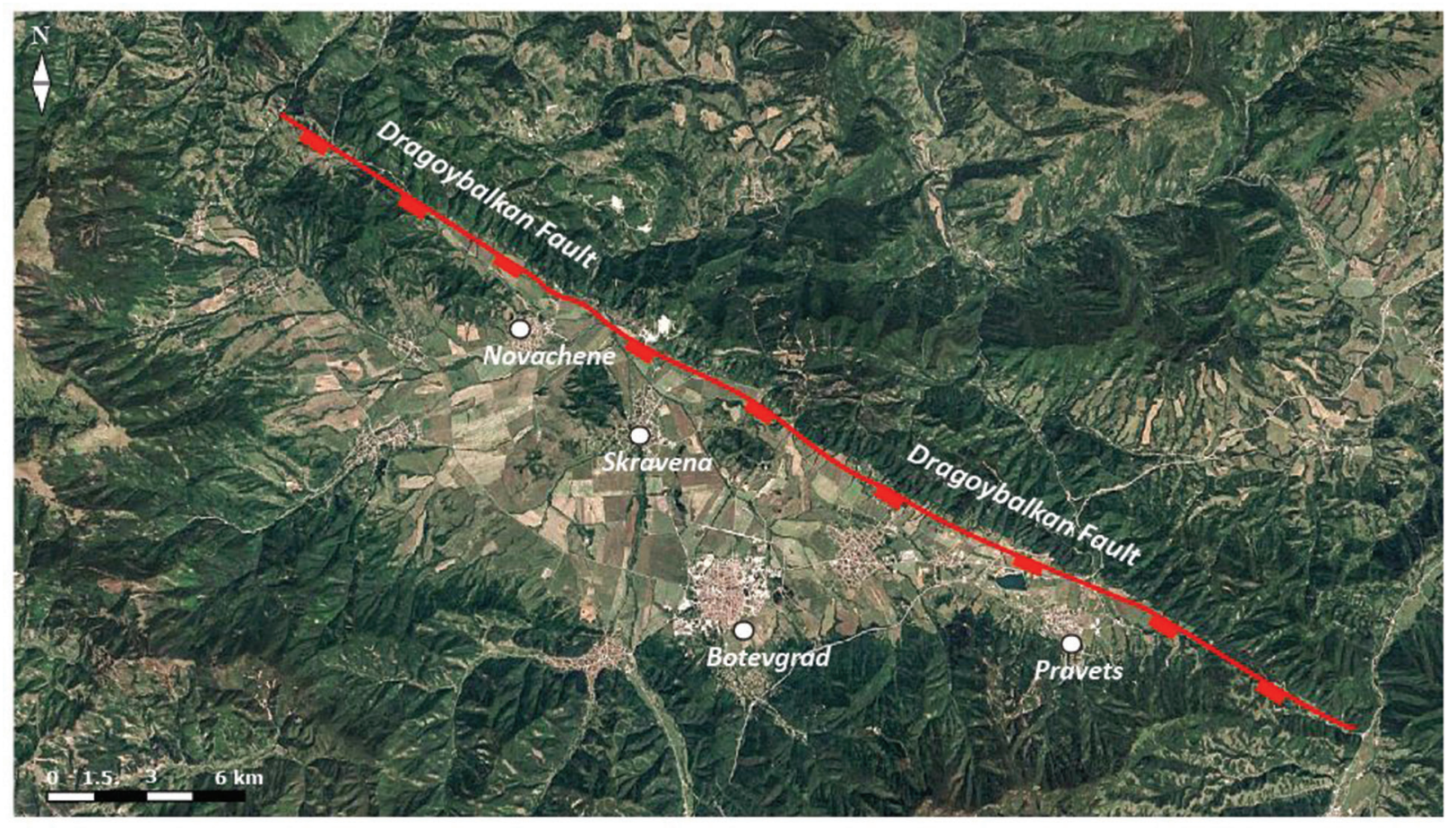

Fig. 5. Google Earth image with well-expressed trace of the Dragoybalkan fault.

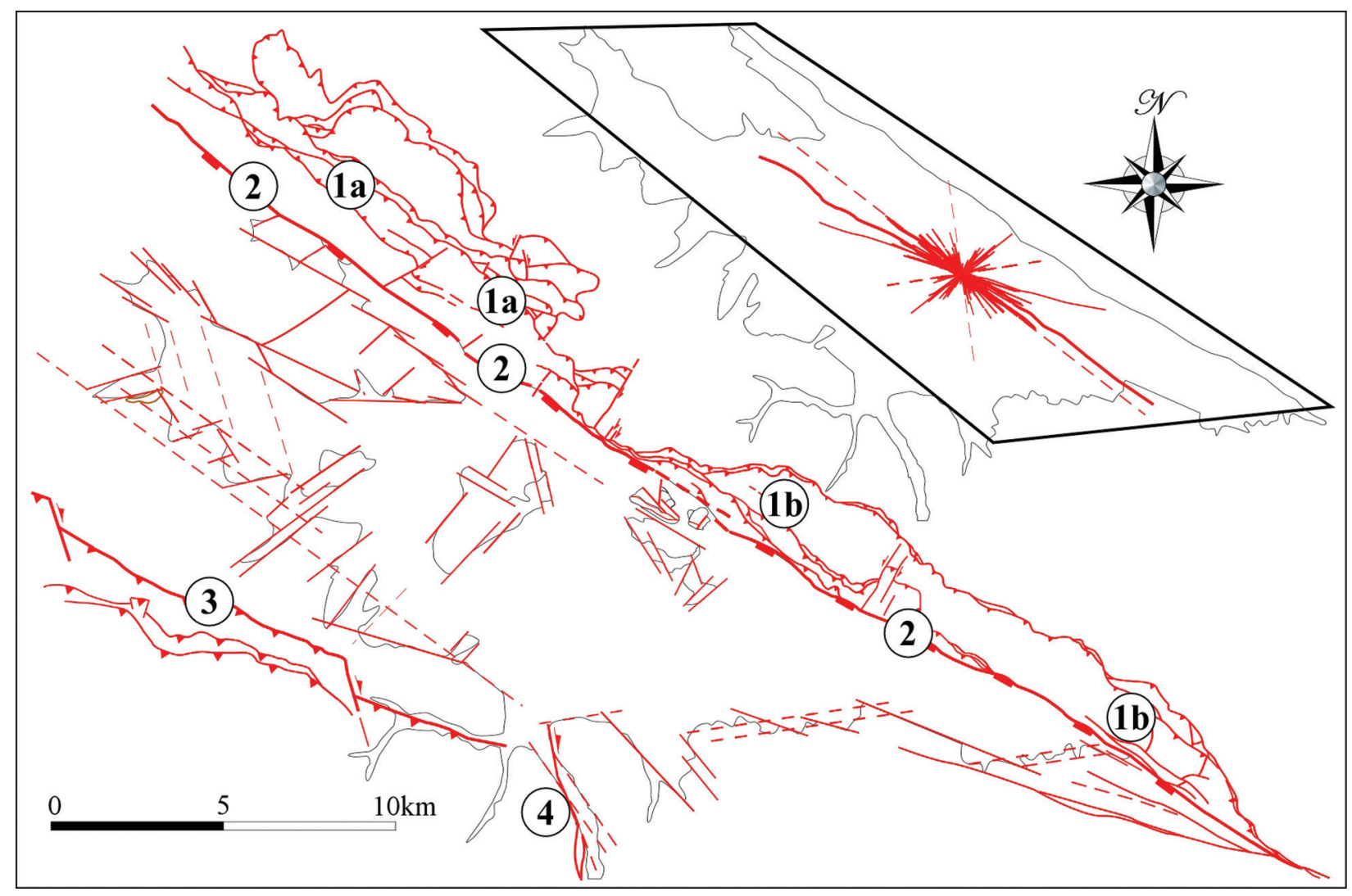

Fig. 6. Sketch map of the fault zones, faults and fragments for the studied area (1-4) and rose-diagram of the faults in the frames of the basin and its boards (top right). 1 - Plakalnitsa fault zone; $1 a$ - Lyutidol-Lipnitsa fault segment; $1 b$ - Temush-Urvich fault segment; 2 - Dragoybalkan fault; 3 - Vidlich dislocation; 4 - Bebresh fault zone. 

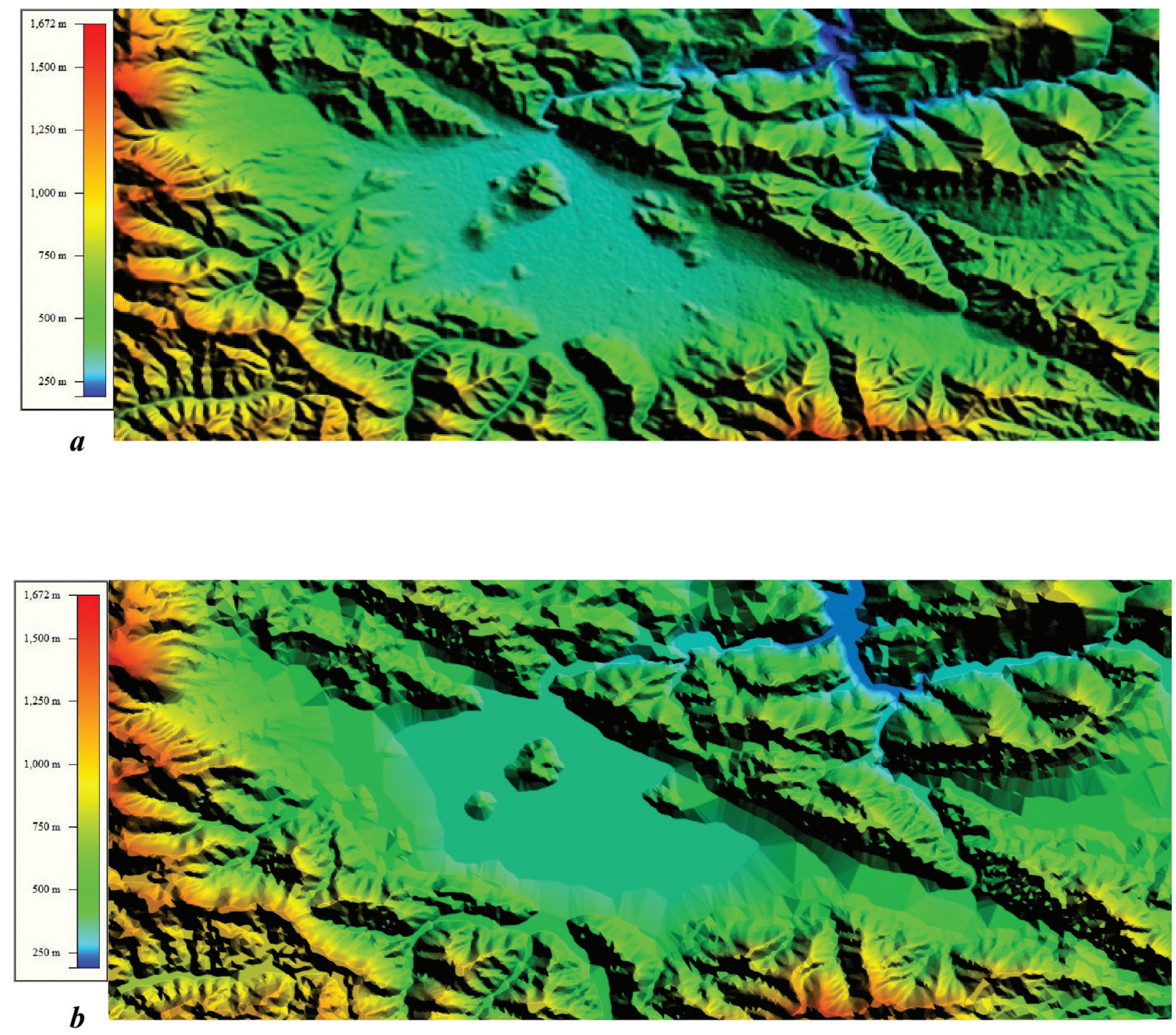

Fig. 7. Digital terrain model (DTM) can represent sudden changes in topography and areas with uniform aspect, essential for identification of tectonically induced morphology. Triangulated irregular network (TIN) interpolation $(b)$ was created with Global Mapper (v15.1) and based on SRTM Worldwide Elevation Data (3-arc-second Resolution) (a).

towards some of the tectonically active boards or depocentres in the frames of the basin was documented. Some cases of cut-off fans, replacement of the alluvial fan heads from the channel mouths, and riverbed migration towards the mountain front indicate tectonic control on deposition.

The distribution of the numerous depocentres, their shapes, possible migration and expansion (Nenov, 1976) indicate multiphase basin evolution as well (Figs 8, 9). Nenov et al. (1972) and Nenov (1976) outlined late Pliocene depocentres (Fig. 8b).

The elongated depocentres are situated close to and parallel to the Dragoybalkan fault, whereas the other three proved in the basin accommodation space are related to the Bebresh River drainage systems (Figs 8, 10). The heterogeneity of the depocentres' distributions does not confirm the half-graben model of basin formation. The wedge-shaped depocentres along the Dragoybalkan fault, the existence of push-up blocks and their rotation, and the tilting of the blocks along the orthogonal or oblique to the basin axes secondary faults indicate the right-lateral displacements of the blocks on both flanks of the Dragoybalkan fault followed by later extensional events outlining the basin accommodation space.

The shape and orientation of the Pliocene depocentres and their expansion during the later stages of the basin evolution indicate reorientation of the 


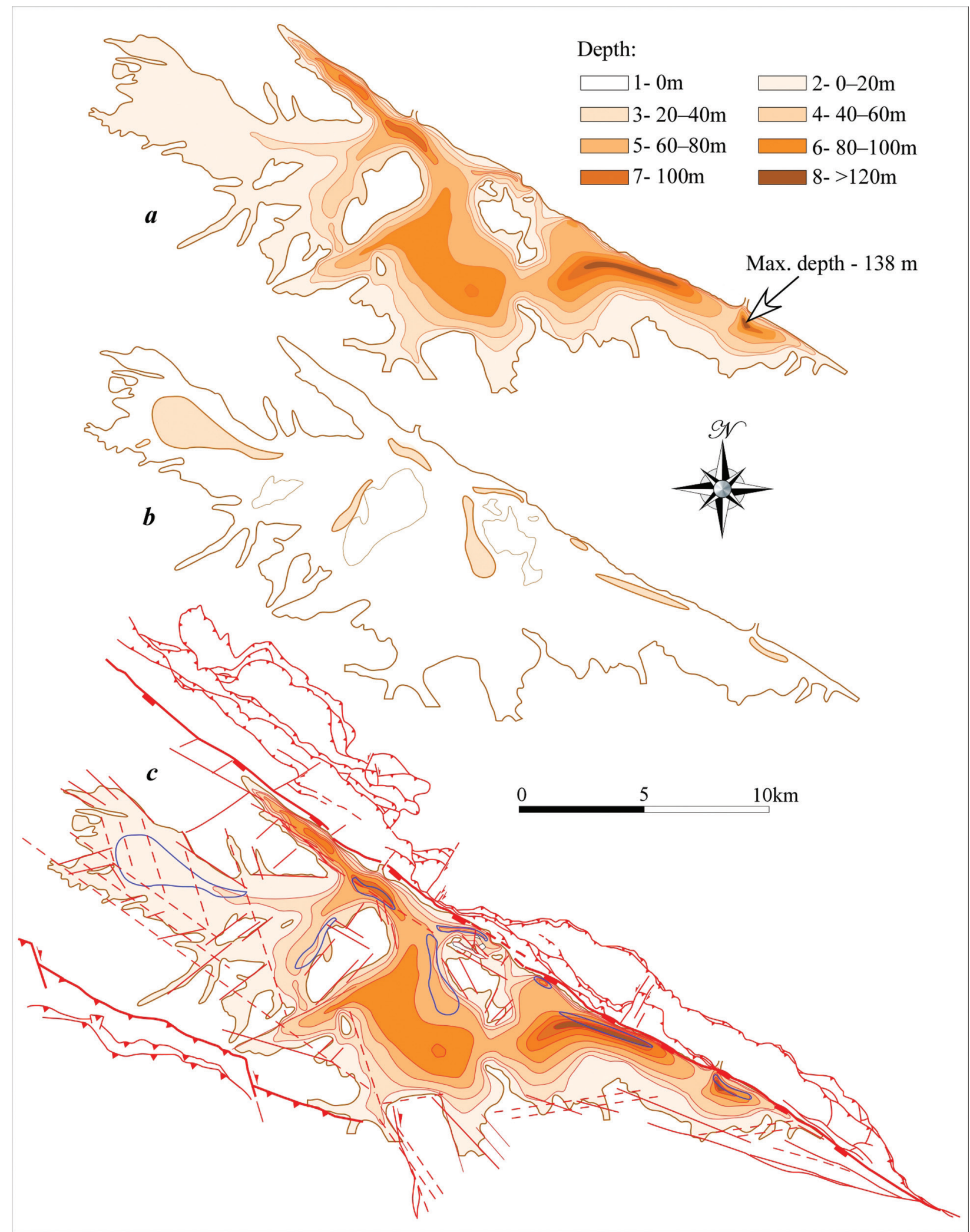

Fig. 8. Sketch map of the Botevgrad basin depocentres (after Nenov et al., 1972; Nenov, 1976): a) with sedimentary fill thickness; b) late Pliocene depocentres; $c$ ) overimposed maps of depocenters and faults. 


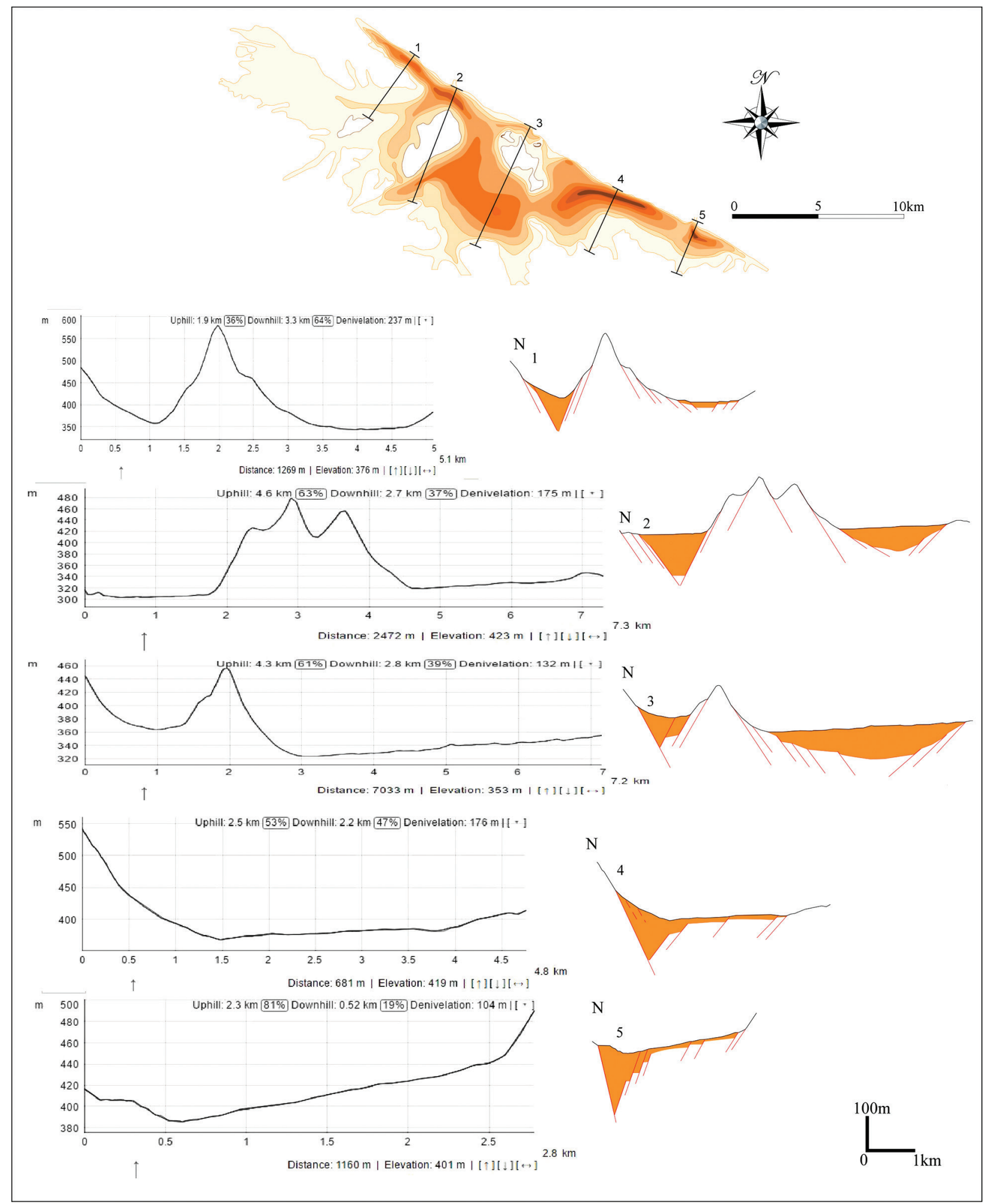

Fig. 9. Sketch map of the Botevgrad basin depocentres with cross-sections showing the heterogeneity of distribution and sedimentary-fill thickness. Note the wedge-shaped depocentres along the Dragoybalkan fault. 


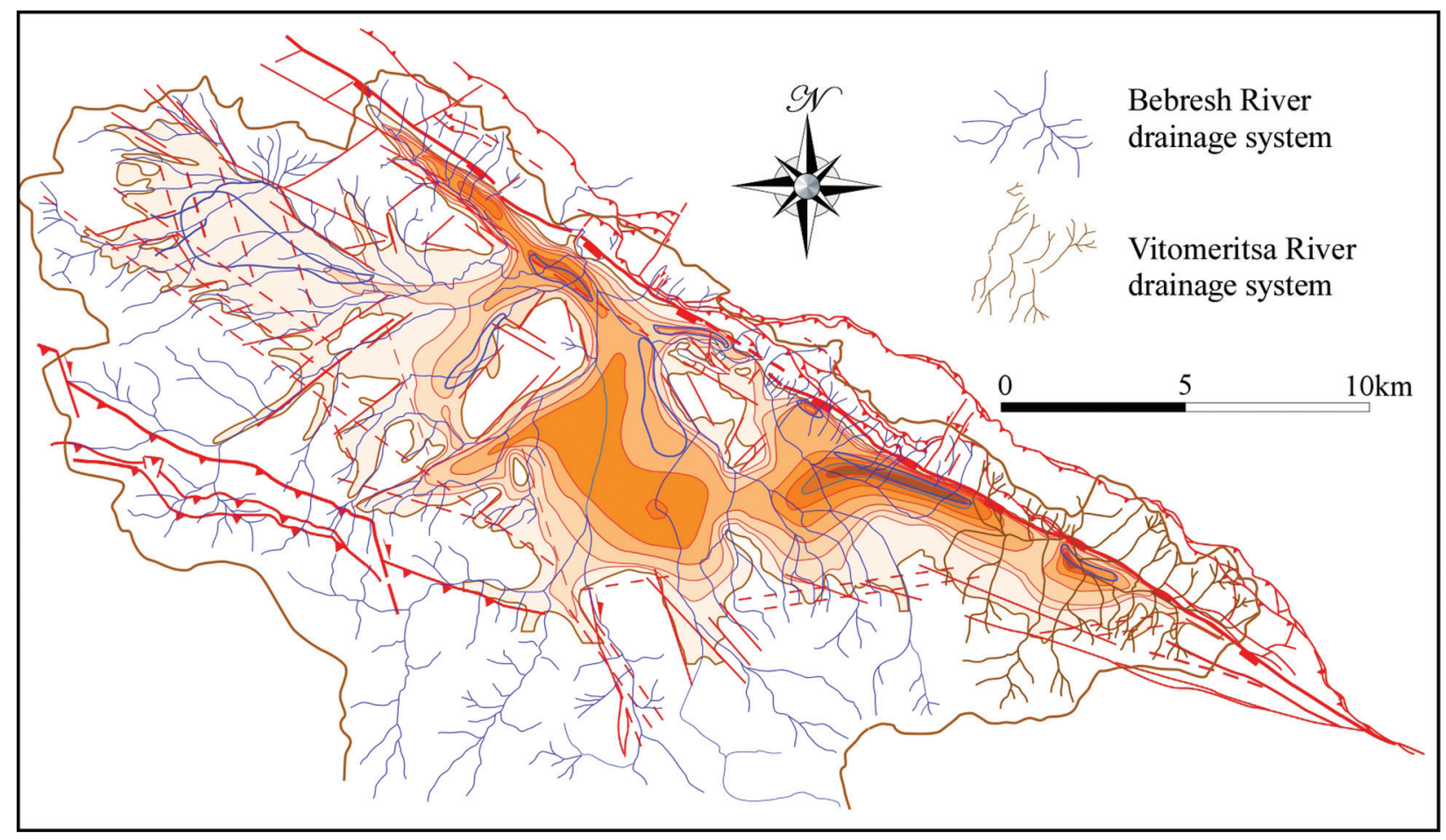

Fig. 10. Sketch map of the Botevgrad basin with overimposed drainage systems, depocentres and faults.

western part of the Vitomeritsa River drainage system toward the Bebresh one, most probably due to progradation of alluvial fans (Fig. 10).

\section{DISCUSSION AND CONCLUSIONS}

The post-Illyrian extension (45-40 Ma to present) resulted in the development of differing in distribution and characteristics basin systems upon the Balkan fold-thrust belt allochthon (Kounov et al., 2017). The Botevgrad basin is a part of the youngest late Pliocene-Quaternary system, developed on the front of the orogenic belt along the Plakalnitsa fault zone, which indicates activity and reactivation at least from Variscan times to present days.

According to previous studies, the Botevgrad basin is interpreted as a half-graben formed by subsidence of the Dragoybalkan fault's SSW block, mainly due to its linear geometry and longer trace. Field data suggest that the basin formation is more complicated: all basin boards are fault predestined and the documented dextral transtension indicates most probably the collapse of one positive flower structure, which was a result of former transpressional deformations. The other not-so-linear boards could be explained by the segmentation of the faults, Riedell shearing, rotation of the intra-basinal blocks and the rheology of the basement lithologies (mainly Palaeozoic low-grade metamorphites and granitoids that have undergone many deformational events). The structural data, basin shape and other basin features related to its evolution, especially the right-lateral translations along the Plakalnitsa and Dragoybalkan faults, allow the Botevgrad basin to be interpreted as pull-apart basin in terms of mechanism of formation. Morphologically, the basin can be characterised as a graben (not half-graben) with complicated internal composition and distribution of the basement blocks.

The distribution of the numerous depocentres, especially the late Pliocene ones, the drainage systems' orientation, watershed shape and depositional system migration indicate polyphasic basin evolution. The West Balkan is characterised as a part of the Early Alpine orogenic belt without deposition of younger than Early Cretaceous rocks but affected by Late Alpine tectonic events. This suggests that, at least from the end of Early Cretaceous, the thickskinned orogen of the West Balkan Zone was dry land with respectively a drainage system developed on its northern board, supplying resedimented material towards the foreland remnant basin on top of the Fore-Balkan and the Moesian platform towards the Severin basin north-westwards.

The expansion of the Late Cretaceous-Palaeogene (late Campanian-middle Palaeocene) basin 
system over the Fore-Balkan area drowned the drainage system, but the dominated by compressional tectonics coarse-grained depositional system during the late Paleocene-middle Eocene indicates alluvial feeding.

During the middle Eocene-early Miocene, the alluvial system is supposed to have been prograding to the Carpathian foreland basin, at least early on in its evolution.

In the late Pliocene-Quaternary, the extensional reactivation of the Dragoybalkan fault created a "catchment area" infilled with lacustrine and alluvial deposits (maximum 138m), thus the Botevgrad basin may be only a cascade basin along the Bebresh and Vitomeritsa river systems along a long-living and still-active tectonic zone, as also suggested by the incision of the riverbeds in the basin frames and the drainage system prolongation towards the Danube River.

There is no doubt that the Dragoybalkan fault is the main structure controlling the evolution and deposition in the Botevgrad basin, whose geomorphic indices confirm its present-day activity. The position of some riverbeds, very close or along the mountain front in the basin's north-western and southern parts, does not exclude such activities along a part of the other boards or intrabasinal blocks.

\section{REFERENCES}

Angelov, V., Antonov, M., Gerdzhikov, S., Petrov, P., Aydanliyski, G., Kiselinov, H., Valev. V. 2008. Geological Map of the Republic of Bulgaria in scale 1:50 000, Mezdra map sheet. Ministry of Environment and Water, Bulgarian National Geological Survey, Sofia (in Bulgarian).

Angelov, V., Antonov, M., Gerdzhikov, S., Tanatsiev, S., Kiselinov, H., Petrov, P., Valev, V. 2010a. Geological map of the Republic of Bulgaria in scale 1:50 000, Litakovo map sheet. Ministry of Environment and Water, Bulgarian National Geological Survey, Sofia (in Bulgarian).

Angelov, V., Antonov, M., Gerdzhikov, S., Tanatsiev, S., Kiselinov, H., Petrov, P., Valev, V. 2010b. Geological map of the Republic of Bulgaria in scale 1:50 000, Botevgrad map sheet. Ministry of Environment and Water, Bulgarian National Geological Survey, Sofia (in Bulgarian).

Angelov, V., Antonov, M., Gerdjikov, S., Metodiev, L., Kiselinov, H., Sirakov, V., Valev, V. 2010c. Explanatory notes to the geological map of the Republic of Bulgaria in scale 1:50 000, Botevgrad map sheet. Ministry of Environment and Water, Bulgarian National Geological Survey, Sofia, 85 pp. (in Bulgarian).

Bončev, E. 1932. Geologie des Vorbalkans von Orhanie westlich von den Flüssen Bebrež und Malki Iskar (Bulgarien). Review of the Bulgarian Geological Society 4 (2), 85-156 (in Bulgarian, with German abstract).

Bončev, E. 1936. Versuch einer tektonischen Synthese Westbulgariens. Geologica Balkanica 2 (1), 5-48 (in Bulgarian, with German abstract).

Bončev, E. 1946. Basic tectonics of Bulgaria. In: Cohen, E., Dimitroff, Tz., Kamenoff, B. (Eds.). Annuaire de la Direction pour les recherches géologiques et minières en Bulgarie, Série A 4, 336-379 (in Bulgarian).

Bončev, E. (Ed.). 1971. Tectonics of the Forebalkan. Bulgarian Academy of Sciences, Sofia, 584 pp. (in Bulgarian).

Boué, A. 1840. Esquisse géologique de la Turquie d'Europe. Imprimerie de Bourgogne et Martinet, Paris, $190 \mathrm{pp}$.

Burchfiel, C.B., Nakov, R., Tzankov, Tz., Royden, L.H. 2000. Cenozoic extension in Bulgaria and Northern Greece: the northern part of Aegean Extensional Regime. In: Bozkurt, E., Winchester, J.A., Piper, J.D.A. (Eds). Tectonics and Magmatism in Turkey and the Surrounding Area. Geological Society, London, Special Publications 173, 325-352.
Burchfiel, B.C., Nakov, R. 2015. The multiply deformed foreland fold-thrust belt of the Balkan orogeny, Northern Bulgaria. Geosphere 11, 463-490.

Demirev, A., Stoynev, L. 1962. Young magmatites near Botevgrad. Bulletin of the Geological Institute, Bulgarian Academy of Sciences 11, 163-177 (in Bulgarian).

Dewey, J.F., Ryan, P.D., Anderson, T.D. 1993. Orogenic uplift and collapse, crustal thickness, fabrics and metamorphic phase changes - the role of eclogites. In: Prichard, H.M, Alabaster, T., Harris, N.B., Neary, C.R. (Eds). Processes and Plate Tectonics. Geological Society, London, Special Publications 76, 325-343.

Dinkov, E., Nenov, T., Petrov, D., Tsvetkov, G., Darakchieva, S. 1977. Report on the geology of the western part of the Botevgrad valley and the Murgash Mountain. Geofund of the Committee of Geology IV-332 (in Bulgarian).

Gellert, J. 1932. Beobachtungen und Betrachtungen zur Morphologie Westbulgarien Balkanforschung. Institute für $\mathrm{Ge}$ ologie de Universität Leipzig. Zeitschrift für Geomorphologie, VII, 74

Ivanov, Ž. 1998. Tectonics of Bulgaria. Professorship thesis, Sofia University “St Kliment Ohridski”, 579 pp. (in Bulgarian, unpublished).

Ivanov, Z., Petrov, N., Lazarova, A., Nedkova, K. 2004. Structural characteristics of Elatsite field - structure and regional position. Geodynamic settings of formation of Upper Cretaceous magmatic bodies in the region and evaluation of their ore potential. Geofund material "Elatsite MED", 73 pp. (in Bulgarian).

Gerdjikov, I., Vangelov, D., Dotseva, Z. 2015. Tectonic problems in Botevgrad-Etropole part of the Balkanides. Annual of the University of Mining and Geology, Geology and Geophysics 58 (1), 135-139.

Hochstetter von, F. 1872. Die geologischen Verhältnisse des östlichen Teiles der europäischen Türkei. Jahrbuch der Kaiserlich-Königlichen Geologischen Reichsanstalt 22 (4), 331-388.

Kozhoukharov, D., Kozhoukharova, E., Iliev, K., Stereva, M. 1956. Report on the complex geological mapping in scale 1:25 000 for the area between Iskar river and villages Osenovlak and Leskov dol, Svoge district. Geofund of Committee of Geology, IV-53 (in Bulgarian). 
Kotzev, V., Nakov, R., Burchfiel, B.C., King, R., Reilinger, R. 2001a. GPS study of active tectonics in Bulgaria: results from 1996 to 1998. Journal of Geodynamics 31 (2), 189-200.

Kounov, A., Gerdjikov, I., Vangelov, D., Balkanska, E., Lazarova, A., Georgiev, S., Stockli, D., Blunt, E. 2017. First thermochronological constraints on the Cenozoic extension along the Balkan Fold-Thrust Belt (Central Stara Planina Mountain, Bulgaria). International Journal of Earth Sciences 107 (4), 1515-1535.

Nenov, T. 1976. Geomorphology of the Stara Planina and Forebalkan between the Iskar, Malak Iskar and Gabrovnitsa river valleys. $\mathrm{PhD}$ thesis, Sofia University "St Kliment Ohridski”, 302 pp. (in Bulgarian, unpublished).

Nenov, T., Dinkov, E., Stoykov, S. 1972. Presence of Pliocene sediments in the Botevgrad valley. Annual of Sofia University "St Kliment Ohridski" 64 (1), 33-39 (in Bulgarian).

Petrov, N. 2005. Emplacement mechanism of Late Cretaceous subvolcanic magmatic bodies during transpression in the Northern part of Sredna Gora tectonic zone. Annual of Sofia University "St Kliment Ohridski” 98, 43-65.

Roy, M., Royden, L.H., Burchfield, B.C., Tzankov, Tz., Nakov, R. 1996. Flexural uplift of the Stara planina range, Central Bulgaria. Basin Research 8, 143-156.
Steward, C.J., Nemcok, M., Vangelov, D., Higgins, E.R., Welker, C., Meaux, D.P. 2011. Structural and depositional evolution of the East Balkan thrust belt, Bulgaria. American Association of Petroleum Geologists Bulletin 95, 649-673.

Toula, F. 1882. Grundlagen der Geologie des Westlichen Balkans. Denkschriften der Kaiserlichen Akademie der Wissenschaften, Mathematisch-Naturwissenschaftliche Classen, Wien 44 (2), 1-58.

Tzankov, Tz., Angelova, D., Nakov, R., Burchfiel, B., Royden, C.L. 1996. The Sub-Balkan graben system of Central Bulgaria. Basin Research 8, 125-142.

Tzankov, V., Strashimirov, B., Dimitrova, N., Vrablianski, B. 1956. Report to the geology of the Belene Tertiary basin. Annuaire de la Direction pour les recherches géologiques et minières en Bulgarie, Série A 6, 1-45.

Vangelov, D., Gerdjikov, I., Bonev, K., Nikolov, S. 2010. Preliminary data of the Karlovo Basin formation and evolution. Annual of Sofia University "St Kliment Ohridski” 102 (1), 71-106 (in Bulgarian).

Vangelov, D., Gerdjikov, I., Kounov, A., Lazarova, A. 2013. The Balkan Fold-Thrust Belt: an overview of the main features. Geologica Balcanica 42 (1-3), 29-47. 